\title{
A Case of Late-Onset Systemic Lupus Erythematosus with Severe Anemia
}

\author{
MOEKO MATSUMOTO, SHINJIRO KAIEDA, SEIYO HONDA, HIROAKI IDA, \\ TOMOAKI HOSHINO AND TAKAAKI FUKUDA*
}

Department of Medicine, Kurume University School of Medicine, Kurume 830-0011, and

*Center for Rheumatic Diseases, Kurume University Medical Center, Kurume 839-0863, Japan

Received 11 April 2012, accepted 18 February 2013

J-STAGE advance publication 7 August 2013

Edited by TAKASHI OKAMURA

\begin{abstract}
Summary: A 59-year-old woman was referred to our hospital because of severe anemia and leucopenia. Although she developed mild arthralgia without the typical symptoms of systemic lupus erythematosus (SLE), positivity for anti-Sm antibodies led us to a diagnosis of late-onset SLE. Autoimmune hemolytic anemia (AIHA) and suppression of reticulocyte production were considered to have been involved in the etiology of severe anemia. Administration of oral prednisolone (PSL) resulted in a marked improvement of the hematological abnormalities. As late-onset SLE is rare and patients tend to show the typical symptoms less frequently, close attention should be focused on latent symptoms and immunological findings.
\end{abstract}

Key words late-onset SLE, severe anemia, steroid therapy

\section{INTRODUCTION}

Systemic lupus erythematosus (SLE) is a chronic autoimmune disease predominantly affecting young people and showing a well known female predilection $[1,2]$. Age at onset has been recognized as having a modifying effect on the clinical manifestations of SLE, and thus late onset in persons aged 50 years and above may constitute a specific subgroup of SLE [3-5]. Patients with late-onset SLE seem to show a more insidious disease onset, and are less likely to have major organ involvement [1]. This may give rise to a delay in diagnosis due to lack of typical clinical manifestations. Here, we report a case of late onset-SLE associated with severe anemia.

\section{CASE REPORT}

A 59-year-old woman was admitted to our hospital with severe anemia and leukopenia. Upon admis- sion she complained of arthralgia in her ankles and felt fatigue and dyspnea on exertion. Vital signs on presentation included blood pressure 134/62 $\mathrm{mmHg}$, pulse rate 92 per min with a regular rhythm, body temperature $36.0^{\circ} \mathrm{C}$, and respiration rate 22 per min. The palpebral conjunctivae were anemic without bulbar jaundice. On chest auscultation, the heart and breath sounds were clear. The abdomen was soft and flat, and the spleen was not palpable. Neurological status was normal. Peripheral lymphadenopathy and edema were not noted. However, the right ankle was swollen and painful. No skin rash was evident on the face or extremities.

Laboratory evaluation (Table 1) revealed normochromic normocytic anemia (Hb: $5.7 \mathrm{~g} / \mathrm{dl})$, leucopenia $(2000 / \mu l)$, thrombocytopenia $\left(11.1 \times 10^{4} / \mu \mathrm{l}\right)$ and reticulocytopenia $(2.2 \%)$ ). Blood coagulation tests gave normal results. The serum protein level was high at $8.56 \mathrm{~g} / \mathrm{dl}$, and indirect hyperbilirubinemia was detected. The serum level of erythropoietin was high (2440 
TABLE 1.

Laboratory Data on Admission

\begin{tabular}{|c|c|c|c|c|c|c|c|c|}
\hline \multicolumn{3}{|l|}{ 【Hematology】 } & \multicolumn{2}{|l|}{ 【Blood chemistry】 } & \multicolumn{3}{|c|}{ 【Serological test】 } & \multirow[b]{2}{*}{$\mathrm{mg} / \mathrm{dL}$} \\
\hline $\mathrm{RBC}$ & $177 \times 10^{4}$ & $/ \mu \mathrm{L}$ & TP & 8.56 & $g / d L$ & CRP & 0.05 & \\
\hline $\mathrm{Hb}$ & 5.7 & $\mathrm{~g} / \mathrm{dL}$ & Alb & 3.69 & $\mathrm{~g} / \mathrm{L}$ & $\operatorname{Ig} G$ & 3366 & $\mathrm{mg} / \mathrm{dL}$ \\
\hline $\mathrm{Ht}$ & 16 & $\%$ & T.Bil & 1.48 & $\mathrm{mg} / \mathrm{dL}$ & $\operatorname{IgA}$ & 533 & $\mathrm{mg} / \mathrm{dL}$ \\
\hline $\mathrm{MCV}$ & 86 & $\mathrm{fL}$ & D.Bil & 0.07 & $\mathrm{mg} / \mathrm{dL}$ & $\operatorname{IgM}$ & 130 & $\mathrm{mg} / \mathrm{dL}$ \\
\hline $\mathrm{MCH}$ & 35.6 & $g / d L$ & LDH & 583 & $\mathrm{mg} / \mathrm{dL}$ & $\mathrm{C} 3$ & 73 & $\mu \mathrm{g} / \mathrm{mL}$ \\
\hline $\mathrm{MCHC}$ & 33.8 & $\mathrm{~g} / \mathrm{dL}$ & AST & 28 & $\mathrm{U} / \mathrm{L}$ & $\mathrm{C} 4$ & 15 & $\mu \mathrm{g} / \mathrm{mL}$ \\
\hline WBC & 2000 & $/ \mu 1$ & ALT & 20 & $\mathrm{U} / \mathrm{L}$ & $\mathrm{RF}$ & 44 & $\mathrm{IU} / \mathrm{mL}$ \\
\hline Neutro. & 37 & $\%$ & ALP & 262 & $\mathrm{U} / \mathrm{L}$ & Anti-Nuclear Ab. & $\times 160$ & \\
\hline Lymph. & 48 & $\%$ & $\gamma$-GTP & 10 & $\mathrm{U} / \mathrm{L}$ & \multicolumn{2}{|c|}{ Pattern: Nucleolar Cytoplasmic } & \\
\hline Mono. & 13 & $\%$ & BUN & 17.7 & $\mathrm{mg} / \mathrm{dL}$ & Anti-dsDNA Ab. & $(-)$ & \\
\hline eosino. & 2 & $\%$ & $\mathrm{Cr}$ & 0.43 & $\mathrm{mg} / \mathrm{dL}$ & Anti-ssDNA Ab. & $(-)$ & \\
\hline PLT & $11.1 \times 10^{4}$ & $/ \mu \mathrm{L}$ & & & & Anti-U1 RNP Ab. & 34.4 & Index \\
\hline \multirow[t]{2}{*}{ Reticulo. } & 2.2 & $\% o$ & $\mathrm{Fe}$ & 187 & $\mu \mathrm{g} / \mathrm{dL}$ & Anti-Sm Ab. & 52.3 & Index \\
\hline & & & UIBC & 7 & $\mu \mathrm{g} / \mathrm{dL}$ & Anti-SS-A Ab. & 49.5 & Index \\
\hline \multicolumn{2}{|c|}{ 【Hemostatic data】 } & & Haptoglobin & $\leqq 10$ & $\mathrm{mg} / \mathrm{dL}$ & Anti-SS-B Ab. & $(-)$ & \\
\hline PT-INR & 1.11 & & Erithropoietin & 2440 & $\mathrm{mIU} / \mathrm{mL}$ & Lupus anti coagulant & $(-)$ & \\
\hline APTT & 29.6 & second & & & & Anti-cardiolipin Ab. & $(-)$ & \\
\hline FDP & $<2.5$ & $\mu \mathrm{g} / \mathrm{mL}$ & 【Virus Infection】 & & & Direct Coombs test & $(+)$ & \\
\hline \multirow[t]{2}{*}{ Fib } & 224 & $\mathrm{mg} / \mathrm{dL}$ & EBV-VCA-IgG & 160 & Fold & Indirect Coombs test & $(+)$ & \\
\hline & & & EBV-VCA-IgM & $<10$ & Fold & & & \\
\hline 【Urinalysis】 & & & EBNA & 80 & Fold & & & \\
\hline Protein & $(-)$ & & Parbo B19-IgM & negative & & & & \\
\hline Occult blood & $(1+)$ & & & & & & & \\
\hline $\begin{array}{l}\text { RBC } \\
\text { 【Feces】 }\end{array}$ & $<1 / \mathrm{HPF}$ & & & & & & & \\
\hline Occult blood & $(-)$ & & & & & & & \\
\hline
\end{tabular}

$\mathrm{mIU} / \mathrm{ml})$. Renal function tests and urinalysis gave normal results, and the CRP level was not elevated. Immunological tests showed that the patient was positive for anti-nuclear antibodies (ANA) with a titer of 1:160 (nucleolar and cytoplasmic pattern). Anti-DNA antibodies were not detected and $\mathrm{C} 3$ and $\mathrm{C} 4$ were normal. Anti-Sm antibodies, anti-U1 RNP antibodies, anti-SS-A antibodies and rheumatoid factor were positive. Anti-cardiolipin antibodies and lupus anticoagulant were negative. Serological studies showed no evidence of recent infection with Epstein-Barr virus or Parvovirus B19.

Bone marrow aspiration revealed normoplastic marrow without trilineage dysplasia (nucleic cell count; $9.6 \times 10^{4} / \mu 1$ ). Myeloid/Erythroid ratio was 3-4:1, suggesting the presence of mild erythroid hypoplasia. No increase in the number of blast cells was observed. Moreover, hemophagocytosis was not detected in the bone marrow. The presence of anti-Sm antibodies, specific antibodies for SLE, and normal bone marrow findings suggested that autoimmunity might be involved in the peripheral hematopenia. Positivity in the direct Coombs test, substantial reduction of haptoglobin ( $<10$ normal: $25-176 \mathrm{mg} / \mathrm{dl}$ ) and indirect hyperbilirubinemia suggested autoimmune hemolytic anemia (AIHA) as a complication. The patient was diagnosed as having SLE on the basis of the 1997 American College of Rheumatology revised criteria for classification of SLE, in view of the presence of arthritis, AIHA, leucopenia, positive anti-Sm antibodies and an abnormal titer in ANA. The patient was treated with oral prednisolone (PSL) $50 \mathrm{mg} /$ day, equivalent to 1 $\mathrm{mg} / \mathrm{day} / \mathrm{kg}$ body weight. As shown in Fig. 1, initiation of PSL resulted in an evident improvement of the anemia, leucopenia and reticulocytopenia. Reduction of the PSL dose was possible, and the patient was dis- 
charged from hospital in an improved condition. The serum haptoglobin level became normalized during the subsequent outpatient course.

\section{DISCUSSION}

SLE is an autoimmune disease that predominantly affects women under 50 years of age and involves multiple organ systems, mainly the kidneys, cardiovascular system, skin, and central nervous system. In a national survey of 1614 SLE patients in Japan, onset in persons aged 50 and above was rare at 6.4\% [6]. Generally, the onset is insidious, and the interval between onset and diagnosis is longer than in younger patients $[7,8]$. Although prior studies have suggested that late onset-SLE is associated with a benign clinical course and better prognosis than SLE in younger patients [1,9], some authors have considered that the degree of organ damage is greater in late onset-SLE $[10,11]$. Although our present patient had mild erythroid hypoplasia, severe anemia was evident, with a minimum $\mathrm{Hb}$ level of $3.9 \mathrm{mg} / \mathrm{dl}$ (Fig. 1). Thus, early diagnosis and treatment is clearly necessary for patients with late onset-SLE.

In late onset-SLE patients, serositis (pericarditis, pleuritis), interstitial pulmonary disease and Sjögren's syndrome are more prevalent, whereas lupus nephritis, neuropsychiatric illness and skin manifestations are uncommon [1,7]. Furthermore, Raynaud's phenomenon, alopecia and lymphadenopathy are present less frequently in elderly patients $[1,12]$. Arthritis, arthralgia and findings resembling polymyalgia rheumatica are initial manifestations of late onset-SLE [13]. Consistent with these features, the present patient had arthritis in her left ankle and lacked typical symptoms such as skin manifestations. Cytopenias are found more commonly in late onset-SLE, and were present as a complication in this patient [14]. Although it has been reported that anti-ds DNA antibodies and anti-Sm antibodies are present less frequently in late onset-SLE patients [1,9], some authors have demonstrated a higher prevalence of anti-Sm antibodies in both younger and elderly patients [7]. Anti-Sm antibodies were detected in the present case, and this led us to the diagnosis of SLE. Diagnosis of SLE in elderly individuals is difficult because of the lack of typical physical and laboratory features that are usually present in younger patients. Therefore, careful attention needs to be paid to latent symptoms and immunological laboratory findings.

Although it was initially suspected that anemia in SLE was mainly a result of antibody-induced erythrocyte damage, evidence to date indicates that its causes can vary and that the pathogenesis may be immune or non-immune [15]. In the present case, bone marrow examination excluded various syndromes of hemopoi-

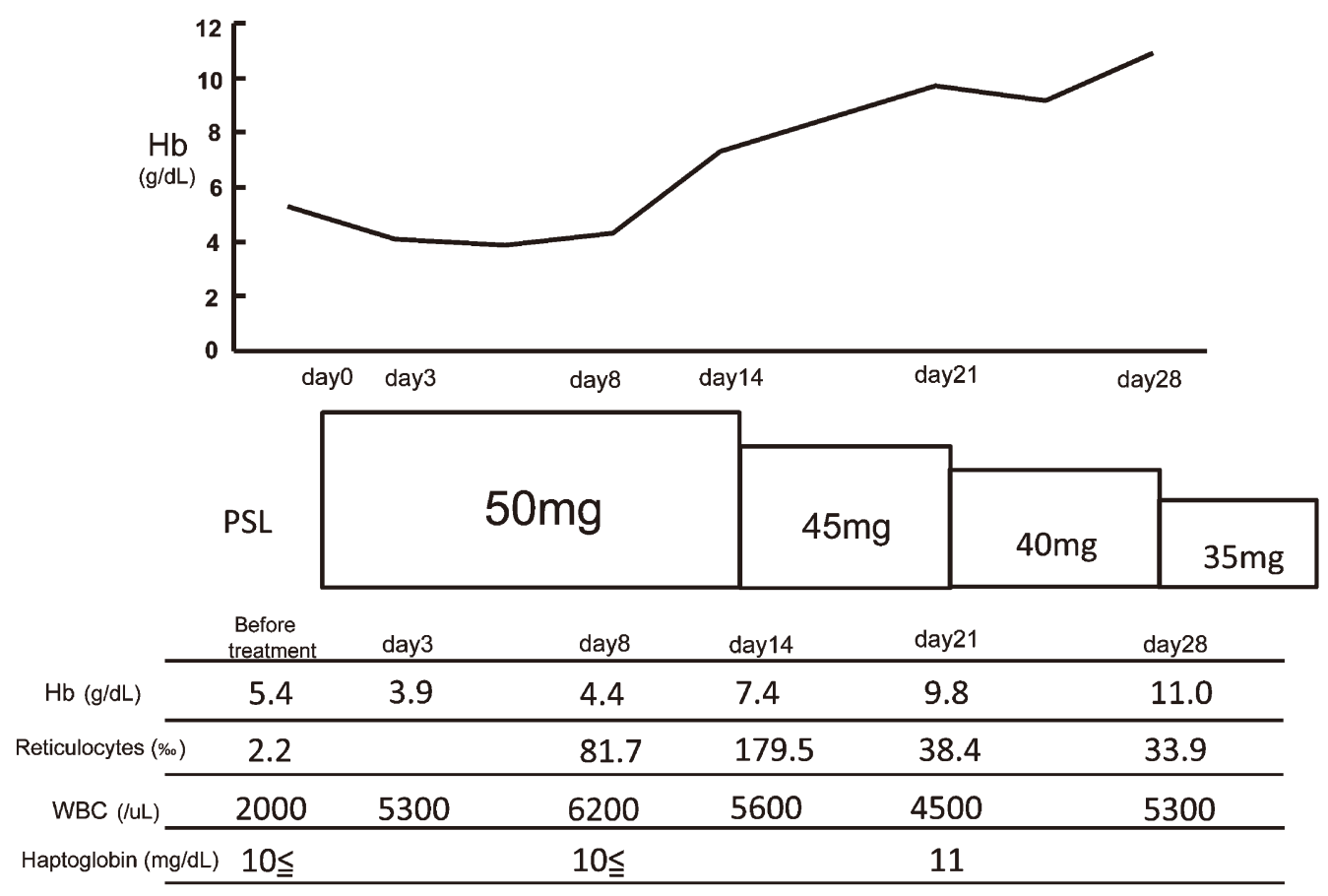

Fig. 1. Clinical course of the patient. PSL: prednisol. 
etic failure, such as aplastic anemia, myeloid line hypoplasia, and pure red cell aplasia. Indirect hyperbilirubinemia, substantial reduction of the serum haptoglobin level, and positivity in the direct Coombs test suggested AIHA as a complication. Although no elevation of the reticulocyte count was evident in the peripheral blood, pathogenic T cells in SLE patients may mediate suppression of erythroid production and abrogate any reactive elevation of the reticulocyte count in AIHA [16]. In this patient, AIHA and inhibition of reticulocyte production were considered to have been involved in the etiology of the severe anemia. Furthermore, the numbers of reticulocytes and the levels of hemoglobin and haptoglobin recovered after the start of steroid therapy, and thus autoimmunity-induced damage to blood cells may have occurred.

In conclusion, although SLE occurs rarely in patients of advanced age, discrimination of late onsetSLE in the elderly is important in Japan, in view of the increase in the proportion of aged individuals in the population. Careful attention to physical and immunological features is required in order to avoid any delay in diagnosis.

\section{REFERENCES}

1. Cervera R, Khamashta MA, Font J, Sebastiani GD, Gil A et al. Systemic lupus erythematosus: clinical and immunologic patterns of disease expression in a cohort of 1,000 patients. The European Working Party on Systemic Lupus Erythematosus. Medicine (Baltimore) 1993; 72:113-124.

2. Jacobsen S, Peterson J, Ullman S, Junker P, Voss A et al. A multicentre study of 513 Danish patients with systemic lupus erythematosus. Disease manifestations and analyses of clinical subsets. Clin Rheumatol 1998; 17:468-477.

3. Pu SJ, Luo SF, Wu YJ, Cheng HS, and Ho HH. The clinical features and prognosis of lupus with disease onset at age 65 and older. Lupus 2000; 9:96-100.

4. Sayarlioglu M, Cefle A, Kamali S, Gul A, Inanc M et al.
Characteristic of patients with late onset systemic lupus erythematosus in Turkey. Int J Clin Pract 2005; 59:183-187.

5. Padovan M, Govoni M, Castellino G, Rizzo N, Fotinidi M et al. Late onset systemic lupus erythematosus: no substantial differences using different cut-off ages. Rheumatol Int 2007; 27:735-741.

6. Hashimoto H, Hirose S, Kano S, Tsunematsu T, and Kabasawa K. Studies on clinical subsets and severity of systemic lupus erythematosus based on a 1987 questionaire conducted in Japan: clinical analysis of the outcome and treatments in clinical subsets. Ryumachi 1992; 32:27-38 (in Japanese, Abstract in English).

7. Font J, Pallares L, Cervera R, Lopez-Soto A, Navarro M et al. Systemic lupus erythematosus in the elderly: clinical and immunological characteristics. Annals of the rheumatic Diseases 1991; 50: 702-705.

8. Pu SJ, Luo SF, Wu YJ, Cheng HS, and Ho HH. The clinical features and prognosis of lupus with disease onset at age 65 and older. Lupus 2000; 9: 96-100.

9. Rovensky J and Tuchynova A. Systemic lupus erythematosus in the elderly. Autoimmunity Reviews 2008; 7:235-239.

10. Maddison P, Farewell V, Isenberg D, Aranow C, Bae SC et al. The rate and pattern of organ damage in late onset systemic lupus erythematosus. J Rheumatol 2002; 29:913-917.

11. Mak SK, Lam EK, and Wong AK. Clinical profile of patients with late-onset SLE: not a benign subgroup. Lupus 1998; 7:23-28.

12. Ward MM and Studenski RP. A meta-analysis of the clinical manifestations of older-onset systemic lupus erythematosus. Arthritis Rheum 1989; 32:1226-1232.

13. Hutton CW and Maddison PJ. Systemic lupus erythematosus presenting as polymyalgia rheumatica in the elderly. Annals of the Rheumatic Diseases 1986; 45:641-644.

14. Knockaert DC, Vanderschueren, and Blockmans D. Fever of unknown origin in adults: 40 years on. J Intern Med 2003; 253:263-275.

15. Ginnouli S, Voulgarelis M, Ziakas PD, and Tzioufas AG. Ananemia in systemic lupus erythematosus: from pathophysiology to clinical assessment. Ann Rheum Dis 2006; 65:144-148.

16. Yamasaki K, Niho Y, and Yanase T. Erythroid colony forming cells in systemic lupus erythematosus. J Rheumatol 1984; 11:167-171. 